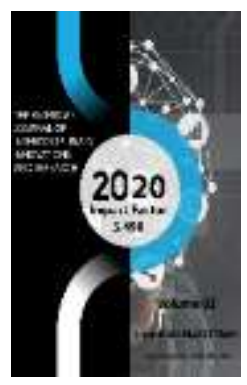

\title{
Surkhan Oasis In The Bronze Age
}

\author{
Baxtiyor Sattarovich Safarov \\ Teacher, Department Of History Of Uzbekistan And Source Studies Of Termez State \\ University, Uzbekistan
}

Journal Website:

http://usajournalshub.c

om/index,php/tajiir

Copyright: Original content from this work may be used under the terms of the creative commons attributes 4.0 licence.

\section{ABSTRACT}

The Surkhandarya oasis, located in the southern part of Central Asia, is a favorable area for agriculture due to its geographic location and climate. In the Bronze Age, a sedentary agricultural culture was formed in the oasis, which was called the Sapalli culture. In this article, the economic, social and cultural life of the oasis in the Bronze Age is scientifically studied on the basis of archeological sources.

\section{KEYWORDS}

Surkhan oasis, Sapalli culture, irrigation, Sapallitepa, Djarkutan, Andronovo culture, agriculture and animal husbandry, pottery, economic ties, handicrafts, cattle breeding.

\section{INTRODUCTION}

Bronze is one of the most important discoveries in human history. Bronze-made tools of labor accelerated the level of development of society. According to researchers, due to the development of cocktail tools of the Bronze Age in the late III and early II millennia BC, agriculture and animal husbandry are well developed in almost all parts of Surkhandarya. 
In the first quarter of the 2nd - millennium BC, important changes took place in the history of the oasis; during this period, a culture based on irrigation agriculture was formed. The Sapalli culture is attributed to this early studied site. The Sapalli culture existing in the period of the 17 th - 10th centuries $B C$ is one of the cultures of the late Bronze Age of the ancient East.

During this period, people began to separate the craft from traditional farming, and also gradually began to establish a system of canals for artificial irrigation of land. One of the earliest monuments of this period is Sapallitepa, located on the banks of Ulanbulaksay.[6, p. 18-31] In this area, the settlement of Dzharkutan was also located, the total area of which was over 100 hectares. It is noteworthy that the ruins of the very first temple of fire worshipers were found on the territory of this settlement.

\section{MAIN PART}

Archaeological evidence, exactly similar to the samples of material culture studied in Sapalli, is widespread in southern Turkmenistan (Namazgah), Western Tadjikistan (Sarazm), northern Afghanistan (Dashtli), and India (Harappa). These cultures in relation to the culture in Sapalli arose much earlier and develops continuously. [1, p. 9-12] Therefore, archeologist A.A. Askarov directly connects the emergence of the Sapalli culture with the fact that a certain group living in the territory of southern Turkmenistan was originally located in the Surkhan oasis.[8;9, p.107-134]

Archaeological excavations in the Surkhandarya oasis have uncovered monuments such as Sapallitepa and Djarkutan. Sapallitepa culture was the first place in southern Uzbekistan based on artificial irrigation, where archaeologists found the remains of agricultural wheat, barley, oats, cotton seeds, pottery and handicrafts. Most importantly, a three-row defensive wall surrounds the fortress, built to protect the tribe from external enemy attack. The total area of the fortress is about one hectare, where in the houses inhabited by eight neighborhoods were found a chimney kiln, in some rooms a sandal place, the remains of plaster. More than 20 pottery jugs, high-quality delicate jugs, jugs, jugs, teapots, bowls, defense weapons, utensils, mirrors, textiles, yarn and silk fabric were found and studied.

The population of Sapallitepa has been in close contact with neighboring peoples since the Bronze Age. In particular, the researcher U.Isarov's research has shown that he established active cultural contacts with nomadic tribes living in the northern regions of Central Asia. [7, p. 18-26]

Between the 18th and 15th centuries BC, the Sapallitepa settlement was bustling with life, but in the 15th century $B C$, due to the drying up of the Ulanbulaksay stream, the Sapallitepa people left the settlement and moved to the Bostonsay area, an ancient tributary of the Sherabad River. Here they formed the first urban culture known as Djarkutan.

The people of Djarkutan have reached a height higher than their ancestors in economic and cultural life. Archaeological excavations here have uncovered seals and signs depicting various animals and birds found in the tombs. The formation of totemistic notions in the religious beliefs of the inhabitants of Djarkutan also indicates the existence of animistic habits. [4, p. 53-59]

A temple of fire was also found in Djarkutan. The temple in the form of a rectangular quadrangle is surrounded by thick outer walls, the edges of which are $45 \times 60$ meters. According to its style and purpose, this building consists of parts that are associated with an economic temple of worship. In the temple of worship there is a long corridor, a terrace, divine objects from holy wells, a treasury presented to the temple for storing various items, as well as a wide square made of bricks, 
in the center of which a holy fire burns under four columns. [5, p. 166-173] This temple was built on the highest point of the city square, which is the only proof that Djarkutan was not only a political and economic center, but also a spiritual and spiritual center for the people of that time in the same region. As mentioned above, people of Djarkutan have their own seals and seals of the city, tribe, and tribal elders, including the image of an eagle fluttering its wings, the movement of four different snakes, and the appearance of various birds and animals. , a picture of wild cats, wild goats, lions, pigs.

Archaeologist A.Askarov has thoroughly studied the ruins and cemeteries of Sapallitepa and Djarkutan villages and scientifically substantiated that these monuments are a stage of ancient Eastern civilization and culture in the territory of ancient Bactria. A. Askarov divided all sources into three stages, the objects from the upper strata of Sapallitepa were called "Sapalli stage", the objects from the upper strata of Sapallitepa and the lower strata of Djarkutan were called " Djarkutan stage", the sources from the upper strata of Djarkutan were called "Mullali stage". [8, p. 5579]

Archaeologist B. Abdullayev studied the sources of the Djarkutan cemetery and scientifically substantiated that the "Mullali stage" consists of two periods: "Kuzali" and "Mullali". [9, p. 11-15] Thus, Sapalli culture was divided into four stages:

1. Sapalli period (XVII - XV centuries BC);

2. Djarkutan period (XV - XIII centuries BC);

3. Kuzali period (XIII - XII centuries BC);

4. Mullali period (XII - X centuries BC).

During the period of Sapalli culture, pottery was made on a pottery wheel. At all stages of pottery culture, pottery, although similar to each other, differs from them. In terms of its subtlety and maturity of form, the ceramics of the " Djarkutan Stage" are superior to all other stage ceramics in their style. The ceramic stage ceramics are heavier and much rougher than the Sapalli stage ceramics.[11, p. 529-542.] The reason for the production of such high-quality ceramics in the south of Uzbekistan is, first of all, the development of a high agricultural culture. The fact that this type of pottery and handicrafts has grown significantly in Sapallitepa was confirmed by the fact that along with the existing workshops, other large structures, such as castles, temples, neighborhoods, have been found.[2, p. 13-17]

According to archeologist A. Askarov, Djarkutan consisted of two parts: "Ark" and "Shahristan". In the "Ark" is the residence of the mayor, the total area of which is 3 hectares. It is surrounded by a thick defensive wall, and to the east and south is Shahristan, inhabited by peasants and artisans, the main inhabitants of the city. As a result of the research, a 20hectare cemetery, about 20 residential areas and patriarchal settlements were identified.

Peculiar objects of the late Djarkutan period are the main direction of the development of the process. During this period, the dead were buried neither in the walls or under the floors of houses, but were buried in separate cemeteries.[10, p. 118-137.]

In the sources of the Kuzali period, the influence of the Andronovo cultures, which lived in the steppes of Siberia, Kazakhstan and Khara-tepe in India, is observed. This circumstance testifies to the fact that in the Bronze Age our ancestors had direct cultural ties with other peoples. These connections contributed to the emergence of innovations not only in sources, but also in traditions and customs, as well as in rituals: after the death of members, there was a custom of burning in fire instead of burial, this is the result of direct cultural ties. 


\section{RESULTS AND DISCUSSIONS}

In the formation of cities, it is historically necessary to have a sedentary economic life of the population and three other factors associated with it. The first is favorable natural conditions, new fertile soil, water and other geographical factors. The second is the emergence of productive irrigation farming and the agro-techniques that provide it. Because that the conditions for the emergence of a system of religious, military and political governance of a stratified society, formed on the basis of economic factors in the emergence of cities. Changes in economic life led to the discovery of artificial irrigation systems in agriculture, the release of water from rivers through new canals to new lands. [3, p. 41]

The population of the Sapalli culture was mainly engaged in agriculture, handicrafts, cattle breeding and hunting. The owners of this culture are the tribes that laid the foundation for early agriculture in Central Asia. On the basis of about three thousand graves in the Jarkutan monument, the anthropological features of the population of the Sapalli culture, that is, the structure of the face and appearance, were studied by the anthropologist T.K. Khojayov. According to the scientist, the population of Jarkutan belongs to the population group of the Eastern Sea, inherent in the European race.[12, p. 69-81]

By the 10th century BC, the Sapalli culture fell into decay. Some scientists associate the reason for the decline in culture with environmental conditions, others associate it with soil salinization, and some archaeologists emphasize that this happened as a result of invasions by alien tribes. These two opinions require comment. If the cultivated lands of the Sherabad Valley in the Bronze Age were saline, then life in the Bustansai basin and its environs would have ceased for several centuries. Imagine, life in this oasis was always in full swing. The second theory even requires explanation. It should be noted that at that time there was not even such a military force and culture that could be compared with the culture of Sapalli, nevertheless, it is considered the absence of a single improved government in society, that is, the absence of a state and a state system.

The following discoveries were made in the Bronze Age in the Surkhandarya oasis:

- Use of plow and animal power in tillage;

- Discovery of spinning and weaving machines in the textile industry of handicrafts;

- Grinding in ceramics, discovery of metal melting and casting technology;

- $\quad$ Use of pets as transport;

- Transition to the construction of residential and monumental buildings on a planned basis in construction;

- The invention of astrology, sundial, calendar on the basis of accumulated knowledge about the environment.

In the Bronze Age, of the social groups of society, the leaders were only elders, but they, as leaders, could not unite the rest of the groups. As a result, residents from urban-type settlements (Djarkutan, etc.) were resettled in communities to other habitats. This is the true reason for the crisis of culture and the disappearance from the scene of history of rich architecture, military art, religious knowledge, highly developed handicrafts and agriculture of the Sapalli period.

\section{CONCLUSION}

The pottery culture is a complex of material culture, which is reflected in archeological sources in the socio-economic, political and ethnocultural development of the Bronze Age tribes engaged in agriculture in the Surkhandarya oasis. These cultural monuments of ancient Oriental civilization have been found and studied in the Surkhandarya region of Uzbekistan (Sapallitepa, Djarkutan, Molali, Bustan). Its oldest and first known monument 
is Sapallitepa, hence the name of the culture. Researchs in Sapallitepa and Djarkutan provides detailed information about the material and spiritual world of Sapalli culture. About 20 monuments of this culture have been found and studied in southern Uzbekistan.

For the Sapalli culture, the majestic architecture of raw bricks, irrigated agriculture, and highly developed multi-disciplinary handicrafts, especially pottery, metallurgy, jewelry, textiles, and leather processing, are well developed. Fire worship played an important role in religious beliefs.

\section{REFERENCES}

1. Abdukayumov Asror Rayimovich. Early settlements of Central Asia as a factor of formation of first societies (on example of the settlement of Sarazm). ESR. № 5-6 2020. Doi:10.29013/ESR-205.6-9-12.

2. Шайдуллаев Ш. Б. Северная Бактрия в эпоху раннего железного века //Ташкент: Фан. - 2000.

3. Lhuillier J. Ladislav Stančo, Shapulat Shaydullaev, Anna Augustinova, Jakub Havlík, Tomáš Smělý, Alisher Shaydullaev, Odiljon Khamidov, Vlastimil Novák."Preliminary Report for the Archaeological Survey in the Baysun District (South Uzbekistan), Season 2017" //Abstracta Iranica. Revue bibliographique pour le domaine irano-aryen. - 2019. - T. 40. №. 41.

4. Huff D., Shaydullaev S. Nekotorye rezul'taty rabot uzbeksko-germanskoj ekspeditsii na gorodishche Dzharkutan. - 1999.

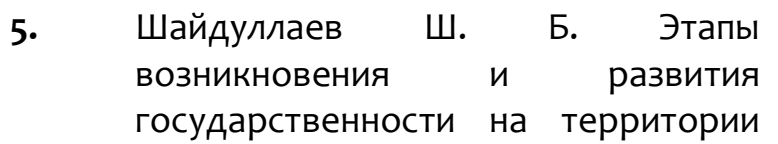

Узбекистана (на примере Бактрии) //АДД. Самарканд. - 2009.

6. Isarov U. I. Reviews of Bactrian irrigation system in the bronze age //Ўтмишга назар журнали. - 2019. - Т. 17. - №. 3.doi: 10.26739/2181-9599-201917-04

7. Isarov U. I. Reviews About Early Nomads In Central Asia //The American Journal of Interdisciplinary Innovations and Research. - 2020. - T. 2. - №. 09. C. 18-26. Doi: 10.37547/tajiir/Volume02Issueo9-03

8. Askarov A. A. Drevnezemledel'českaâ kul'tura èpohi bronzy Ûga Uzbekistana. - Izdatel'stvo" Fan" Uzbekskoj SSR, 1977.

9. Askarov A., Abdullaev B. N. Djarkutan //Taskent (in Russian). - 1983.

10. Avanesova N. A., Dubova N. A., Kufterin V. V. Skeletal remains from buston vi-a Sapalli culture cemetery in Uzbekistan //Archaeology, Ethnology and Anthropology of Eurasia. - 2010. T. 38. - №. 1. - C. 118-137.

11. Luneau E., Bendezu-Sarmiento J., Mustafakulov S. Ceramics and Chronology at Dzharkutan: A Revision of the Periodization of the Sapalli Culture (Uzbekistan c. 2100-1500 BC) //Proceedings of the 8th International Congress on the Archaeology of the Ancient Near East 2012, University of Warsaz. - 2014. - T. 2. - C. 529-542.

12. Grenet F., Khasanov M. The ossuary from Sangyr-tepe (Southern Sogdiana): evidence of the Chionite invasions //Journal of Inner Asian art and archaeology. - 2009. - T. 4. - C. 6981. 